\title{
The Impact of Coup d'états on the Relationship between Stock Market and Exchange Rate: Evidence from Thailand
}

\author{
Kamonchai Rujirarangsan ${ }^{1}$ \\ Surachai Chancharat ${ }^{1 *}$ \\ ${ }^{1}$ Faculty of Business Administration and Accountancy, \\ Khon Kaen University, Khon Kaen 40002, Thailand \\ ${ }^{*}$ Corresponding Author
}

Doi: 10.36941/ajis-2019-0010

\begin{abstract}
This study investigates a dynamic relationship between the Stock Exchange of Thailand (SET) index and the exchange rate of Thai Baht and US dollar (THB/USD) by using daily data for the period of Coup d'état in Thailand during 2006 to 2016. In the long run test, the Johansen's cointegration analysis shows significant long-run relationship during the pre-Coup d'état 2006 and the pre-Coup d'état 2014, but the Coup d'état 2006 and the Coup d'état 2014 are vice versa. The Granger causality tests in all periods show uni-directional causality except the Coup d'état 2006. In the short run test, the SET index shocks in all periods negatively affect the exchange rate of THB/USD except the Coup d'état 2014. In summary, the Coup d'états influence on the compose of the SET index and the exchange rate of THB/USD in both long-run and short-run relationship based on the evidence from Thailand.
\end{abstract}

Keywords: Coup d'état, cointegration, exchange rate, stock market

\section{Introduction}

In the last century, there were nineteenth of successful Coup d'état or attempted Coup d'état in Thailand. The occurrences lead Thailand to the first ranking in Southeast Asia and the fourthranking in the world by the Center for Systemic Peace (Monty and Donna, 2018). This high frequency of adverse events persuades us to examine whether political instability influences a relationship between the financial market and the exchange rate in Thailand.

According to Bunce (1980), the Coup d'état affects the change of political regime, for instance, policies, political style, government performance, and responsiveness. As a following, Dunning (2005a) proposed that the change of political regime influence the financial market. These motivate us to the question that Does Coup d'état affect the financial market and economic stability in Thailand? To answer this question, we select the cointegration test as a tool to find a relationship between the SET index and the exchange rate of THB/USD.

This study investigates the long-run relationship, causal relationship, and short-run relationship. The results might be helpful for the practitioners, and asset allocation investors to assess the Coup d'état situation through their financial market and economic stability.

The remainder of this article is organized as follows. Section 2 describes the literature review. Section 3 analyzes the data for model specifications. Section 4 provides the methodology and also the empirical results and their interpretations. Lastly, Section 5 includes implications and conclusion. 


\section{Literature Review}

Recently, the relationship between exchange rate and stock price is investigated in finance and economic literature. The implication of strong relationship provides essential information for practitioners, investors, and policymakers. In a theoretical study, the foreign currency and stock market are suggested by a flow-oriented model and a stock-oriented model.

First, a flow-oriented model introduced by Dornbusch and Fischer (1980), explains that the changes in the exchange rate have a direct effect on the firm's value and stock price as a sequence. In the analysis of cointegration test that proposed by Kim (2003); Pan et al. (2007); Wongbangpo and Sharma (2002); Wu (2000), the long-run relationship shows that the exchange rate influences the stock market. Second, Branson (1981) and Frankel (1984) suggested a stockoriented model that the change in the stock price effects to the change in the exchange rate. Following, Ibrahim and Aziz (2003) and Maysami and Koh (2000) implemented the cointegration test, and the results explained that the exchange rate is influencing the stock market in the long-run relationship.

In the economic context, the relationship between exchange rates and stock prices are specifically investigated on the events during financial crisis periods. Because, there are stronger effects on both currency and stock markets as documented by Lin (2012); Sui and Sun (2016). During the global financial crisis period from 2008 to 2012, Tsagkanos and Siriopoulos (2013) found a causal relationship between the stock price and the exchange rate of the short-run in US market and the long-run in the European market. In the period of the Asian financial crisis, similarly, Pan et al. (2007) found a causal relationship between the exchange rates and stock markets among the seven Asian countries. In the same way, Fang (2002) found that the exchange rate depreciation effects on the change in the stock market volatility. On the further event, Granger et al. (2000) proposed the evidence from the Asian flu of 1997 to 1998 event. By testing on the stock prices and the exchange rates through nine Asian markets, and the results show significant relationships.

Analogously, in the political economy context, the change of political regime also influences on the financial market as found from Dunning (2005b). The resource-dependent states, the political and economic contexts are potentially related. Similarly, Civilize et al., (2015a) examined the civilian and military governments affect the performance of the stock market. The stock market performance on the civilian government will be better than the military government on the selected countries except for Thailand and Pakistan. Notably, in Thailand, Prasirtsuk (2007) argued that the Asian financial crisis of 1997 formed Thai politics in both agent and agenda. As a sequence, it induced the Thai political crisis and the Coup d'état after that.

Moreover, the political instability is shown the adverse effect to the economic growth as mentioned by Alesina et al. (1996); de Haan and Siermann (1996); Mancur (1991) and McGuire and Olson (1996). Yagci (2018) proposed that the Coup d'états are seemed to be the causes of economic consequences in Turkey. By comparison with the global economic growth, a negative causal effect on Turkish economic growth found during the period of Coup d'état events. Civilize et al. (2015b) indicated that under military rule, the SET index performance would be increased. However, this study showed only the stock market term that lack of conclusion on the military regime and foreign exchange markets.

Furthermore, Lumiajiak et al. (2014) indicated that the Coup d'état 2006 in Thailand has no adversely affected to the SET index and the exchange rate of THB/USD markets. However, the studies individually tested on the SET index and exchange rate of THB/USD by its return volatility and volume. The results then show a negative relationship between the SET index and exchange rate of $\mathrm{THB} / \mathrm{USD}$, and the cointegration has not been proven. As a sequence, the effect of Coup d'état might be misspecified.

\section{Data}

We collect the data starting from July 02, 1997, because Thailand has changed the regime from pegged to a managed float. As a sequence, we can analyze two events of Coup d'état. Then, we divide the data between the daily SET index and the daily exchange rate of THB/USD into four 
subperiod, as shown in figure 1. The dataset is separated into two pairs of equal periods. The first pair is composed of pre-Coup d'état 2006 starts from May 10, 2005, to September 18, 2006, that contains 356 observations and Coup d'état 2006 begins from September 19, 2006, to January 29, 2008, that includes 356 observations. The second pair is composed of pre-Coup d'état 2014 starts from September 12, 2012, to May 21, 2014, that contains 442 observations and Coup d'état 2014 starts from May 22, 2014, to January 29, 2016, that includes 442 observations. Hence, the dataset will be able to analyze for cointegration tests and specified the events with the time horizons.

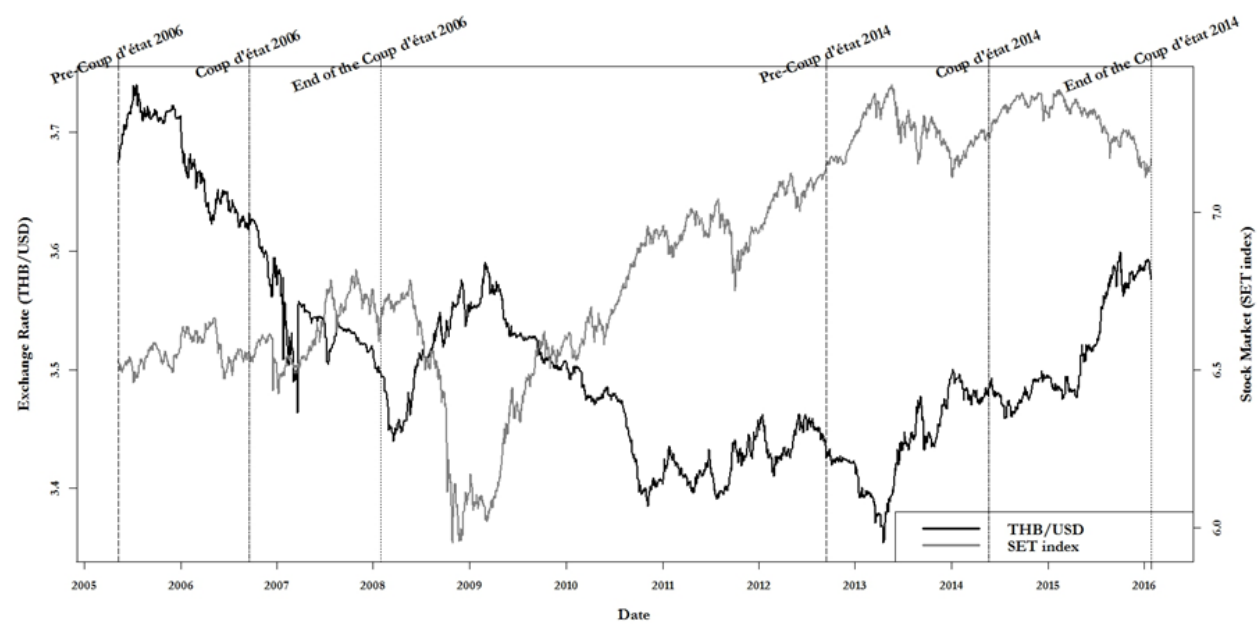

Notes: This figure describes the daily log scale of the exchange rate of THB/USD versus date on the left-hand side axis and the SET index versus date on the right-hand side axis. In the plot, the black line indicates the time series of the exchange rate of THB/USD and the gray line indicates the time series of the SET index. Moreover, the vertical dash lines indicate the selected events on time series that will be investigated.

Figure 1. Time series of the Stock Exchange of Thailand index and the exchange rate of THB/USD

The daily data are collected from datastream and converted to a logarithmic scale. Table 1 presents the statistics of the exchange rate of THB/USD returns and SET index returns. The standard deviations show the stock market returns that are more volatile than the exchange rate of THB/USD returns. The Jarque-Bera tests show significant normality in all series.

Table 1. Descriptive statistics of returns

\begin{tabular}{|c|c|c|c|c|c|}
\hline & Mean (\%) & SD (\%) & Skewness & Kurtosis & Jarque-Bera \\
\hline \multicolumn{6}{|l|}{ Pre-Coup d'état 2006} \\
\hline Exchange rate (THB/USD) & -0.0161 & 0.3267 & -0.5099 & 2.4432 & $106.3493^{* x+x}$ \\
\hline Stock market (SET) & 0.0057 & 0.9416 & -0.9656 & 1.2246 & $23.6804^{* * *}$ \\
\hline \multicolumn{6}{|l|}{ Coup d'état 2006} \\
\hline Exchange rate (THB/USD) & -0.0338 & 0.7556 & 2.9791 & 79.0564 & 94327.1800 \\
\hline Stock market (SET) & 0.0188 & 1.5486 & -2.2263 & 37.1838 & 21056.6100 \\
\hline \multicolumn{6}{|l|}{ Pre-Coup d'état 2014} \\
\hline Exchange rate (THB/USD) & 0.0093 & 0.3287 & -0.5814 & 6.1972 & $741.9513^{\min }$ \\
\hline $\begin{array}{l}\text { Stock market (SET) } \\
\text { Coup d'état } 2014\end{array}$ & 0.0267 & 1.1088 & -0.4619 & 3.3723 & $228.8858^{x \pi x}$ \\
\hline Exchange rate (THB/USD) & 0.0216 & 0.2925 & -0.0558 & 2.5506 & $122.4271_{\ldots *}^{* * *}$ \\
\hline Stock market (SET) & -0.0170 & 0.8152 & -0.4432 & 3.3935 & $230.3002^{\text {s*xt }}$ \\
\hline
\end{tabular}

Notes: " indicates significance at the $1 \%$ levels. The table presents the descriptive statistics for the exchange rate of THB/USD returns and the SET index returns of pre-Coup d'état and Coup d'état periods from 2006 to 2016. The mean and standard deviation (SD) of returns are reported in percentage. 


\section{Methodology and Empirical Results}

\subsection{Unit root test and cointegration test}

In this study, the Augmented Dickey-Fuller (ADF) tests with the drift model proposed by Dickey and Fuller (1981) is used to test for stationarity as following

$$
\Delta y_{t}=\omega+\eta y_{t-1}+\sum_{j=1}^{p} \psi_{j} \Delta y_{t-j}+\varepsilon_{t}
$$

where $\omega$ is the constant term, $\Delta y_{t}$ is the first difference of time series data, $p$ is the lag order terms of the autoregressive process, and $\varepsilon_{t}$ is the error term. We use the Akaike's information criterion (AIC) to avoid biased estimation of the optimal lag length. From table 2, all series show non-stationarity in the levels or $\mathrm{I}(0)$ processes, but stationary in the first differences or $\mathrm{I}(1)$ processes. As a result, the cointegration tests are enabled to test for the long-run relationship between the exchange rate and the stock market.

Table 2. The results of unit root tests-ADF test

\begin{tabular}{|c|c|c|}
\hline & \multicolumn{2}{|c|}{ ADF test } \\
\hline & Levels (log) & $1^{\text {st }}$ differences \\
\hline \multicolumn{3}{|l|}{ Pre-Coup d'état 2006} \\
\hline Exchange rate (THB/USD) & -0.0798 & $-12.9287^{* * *}$ \\
\hline Stock market (SET) & -2.3525 & $-16.3430^{* * *}$ \\
\hline \multicolumn{3}{|l|}{ Coup d'état 2006} \\
\hline Exchange rate (THB/USD) & -0.6800 & $-14.9219^{* * * x}$ \\
\hline Stock market (SET) & -0.2206 & $-14.9302^{* * *}$ \\
\hline \multicolumn{3}{|l|}{ Pre-Coup d'état 2014} \\
\hline Exchange rate (THB/USD) & -2.0884 & $-12.2442^{* * * x}$ \\
\hline Stock market (SET) & -1.3810 & $-13.8792^{* * *}$ \\
\hline \multicolumn{3}{|l|}{ Coup d'état 2014} \\
\hline Exchange rate (THB/USD) & -2.1609 & $-15.3781^{* * *}$ \\
\hline Stock market (SET) & -0.7513 & $-14.3484^{x *}$ \\
\hline
\end{tabular}

Notes: "indicates significance at the 1\% levels. The null hypothesis of ADF test is that the series is non-stationary or a unit root $(\gamma=0)$ and against the alternative that stationary $(\gamma \neq 0)$.

According to the review of the long-run relationship proposed by Gonzalo (1994), Johansen's test performs as the best estimator. As a sequence, the cointegration model found by Johansen (1988, 1991 ) is used for this study. The Johansen's test analyzes the multivariate maximum likelihood on the vector error correction model (VEC) as shown following

$$
\Delta C_{t}=\Pi C_{t-1}+\Gamma_{1} \Delta C_{t-1}+\cdots+\Gamma_{q} \Delta C_{t-q}+\Psi D+e_{t}
$$

where $\Delta C_{t}$ is the vector $(\mathrm{K} \times 1)$, $\Pi$ is $\Omega \cdot \Gamma^{\prime}$, where $\Omega$ defines the matrix of error-correction ( $\mathrm{K} \times$ $\mathrm{K}$ ) and $\Gamma$ defines the relation of cointegration parameters, $q$ is the lag order terms of VEC model, $D$ is the vector of nonstochastic variables $(\mathrm{K} \times 1)$, and $e_{t}$ is vector of error term $(\mathrm{K} \times 1)$ as follows $e_{t} \sim N(0, Q)$, where $Q$ defines as the innovations covariance matrix. Also, the nonstochastic variables, seasonal dummy variables, and dummy variables are excluded from the model.

As a result, the cointegration tests are provided by Johansen's trace tests and the maximum eigenvalue test, as reported in table 3. Both pre-Coup d'état 2006 and pre-Coup d'état 2014 show the existence of the cointegrating relationship between the exchange rate of THB/USD and the SET index, however, during the Coup d'état 2006 and the Coup d'état 2014 are vice versa.

Table 3. Johansen cointegration tests between the SET index and the exchange rate of THB/USD

\begin{tabular}{lccc}
\hline & Rank & $\lambda$ trace & $\lambda$ max \\
\hline Pre-Coup d'état 2006 & $r=0$ & $27.59^{* *}$ & $20.58^{* *}$ \\
Coup d'état 2006 & $r \leq 1$ & 7.01 & 7.01 \\
& $r=0$ & 14.52 & 11.86 \\
& $r \leq 1$ & 2.66 & 2.66
\end{tabular}




\begin{tabular}{lccc}
\hline & Rank & $\lambda$ trace & $\lambda$ max \\
\hline \multirow{2}{*}{ Pre-Coup d'état 2014 } & $r=0$ & $25.88^{\prime \prime}$ & $20.71^{\prime \prime}$ \\
Coup d'état 2014 & $r \leq 1$ & 5.18 & 5.18 \\
& $r=0$ & 18.86 & 14.44 \\
& $r \leq 1$ & 4.41 & 4.41
\end{tabular}

Notes:" indicates significance at the $5 \%$ levels. The null hypothesis of the trace tests is that there are at most $r$ cointegrating relations and against the alternative of $p$ cointegrating relations. The null hypothesis of the maximum eigenvalue test is that there are $r$ cointegrating relations and against the alternative that $r+1$ cointegrating relations.

\subsection{Granger causality test}

From the Granger causality test proposed by Granger (1969) is applied to the analysis of a causal relationship between the exchange rate and the stock market. The testing model is composed of the bivariate VAR models as shown following

$$
\begin{aligned}
& X_{t}=\sum_{i=1}^{m} \alpha_{i} Y_{t-i}+\sum_{j=1}^{m} \beta_{j} Y_{t-j}+\epsilon_{t} \\
& Y_{t}=\sum_{i=1}^{m} \gamma_{i} X_{t-i}+\sum_{j=1}^{m} \delta_{j} Y_{t-j}+\varepsilon_{t}
\end{aligned}
$$

where $m$ is the lag length of the VAR model, $\epsilon_{t}$ is the error term of $X_{t}$ and $\varepsilon_{t}$ is the error term of $Y_{t}$. Empirically, table 4 shows the significant uni-directional causality in all periods, except during the Coup d'état 2006. In the pre-Coup d'état 2014 and the Coup d'état 2014 show the exchange rate of THB/USD Granger-cause the SET index. However, the pre-Coup d'état 2006 shows the SET index Granger-cause the exchange rate of THB/USD.

\begin{tabular}{|c|c|c|c|c|}
\hline & Inference & & F-test & $p$-value \\
\hline \multirow{2}{*}{ Pre-Coup d'état 2006} & No causality & (THB/USD) $\nRightarrow S E T$ & 1.4522 & 0.2286 \\
\hline & Uni-directional causality & $\mathrm{SET} \Rightarrow(\mathrm{THB} / \mathrm{USD})$ & 3.3331 & $0.0683^{x}$ \\
\hline \multirow{2}{*}{ Coup d'état 2006} & No causality & (THB/USD)ÆSET & 1.6528 & 0.1990 \\
\hline & No causality & $\mathrm{SET} \nRightarrow(\mathrm{THB} / \mathrm{USD})$ & 0.5786 & 0.4471 \\
\hline \multirow{2}{*}{ Pre-Coup d'état 2014} & Uni-directional causality & $(\mathrm{THB} / \mathrm{USD}) \Rightarrow \mathrm{SET}$ & 8.3083 & $0.0040^{* * * \pi}$ \\
\hline & No causality & $\mathrm{SET} \nRightarrow(\mathrm{THB} / \mathrm{USD})$ & 0.7676 & 0.3812 \\
\hline \multirow{2}{*}{ Coup d'état 2014} & Uni-directional causality & $(\mathrm{THB} / \mathrm{USD}) \Rightarrow \mathrm{SET}$ & 2.9365 & $0.0869^{*}$ \\
\hline & No causality & SET $\nRightarrow(T H B / U S D)$ & 0.0401 & 0.8414 \\
\hline
\end{tabular}

Table 4. Granger-causality test

Notes: "', and indicates significance at $1 \%, 5 \%$, and $10 \%$ levels, respectively. The null hypothesis of the Granger causality is that the exchange rate of THB/USD (SET index) do not Granger-cause the SET index (exchange rate of THB/USD) and against the alternative that the exchange rate of THB/USD (SET index) do Granger-cause the SET index (exchange rate of THB/USD).

\subsection{Impulse-response functions}

We apply the impulse-response functions to verify a dynamic system in the short-run. As can be seen from figure 2 and 3 , the exchange rate of THB/USD responses a negative shock to the SET index. On the other side, the SET index responses a significant low negative shock to the exchange rate of THB/USD. The relationships in all periods remain stable at zero after five days. In the short run, however, the shock from the exchange rate of THB/USD to the SET index shows a positive association only during Coup d'état 2014. For the response to itself, both the exchange rate of THB/USD and the SET index show a significant positive shock then a quick react to zero. Consequently, all the impulse-response functions test show not persistent in more extended periods. 


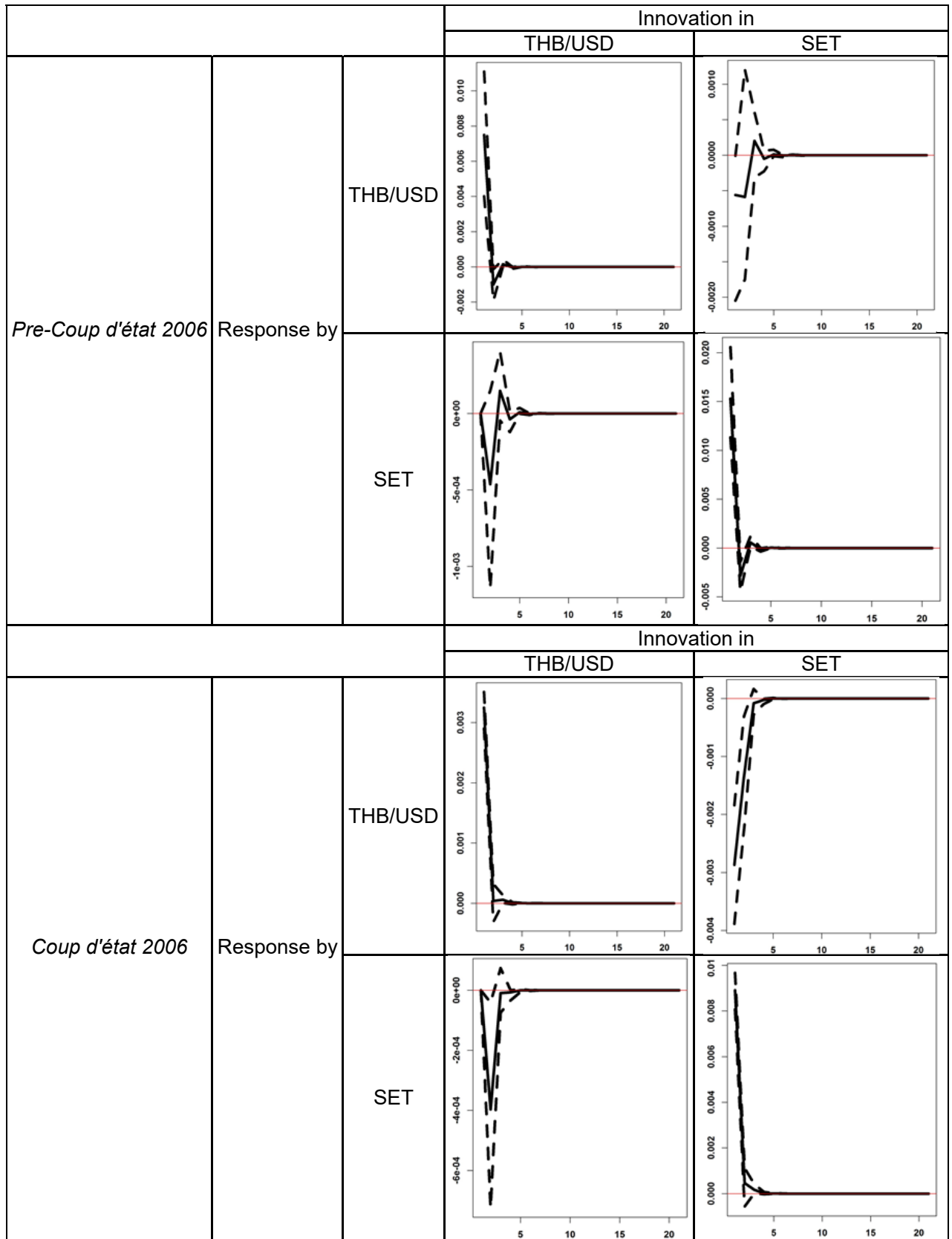

Notes: This figure shows impulse-response of the SET index and the exchange rate of THB/USD during the pre-Coup d'état 2006 and Coup d'état 2006. The subfigures identify the interaction of the SET index and the exchange rate of THB/USD by act as the response to the innovation and vice versa. As a result, the interactions provide as following; exchange rate of THB/USD to exchange rate of THB/USD, the exchange rate of THB/USD to SET index, SET index to exchange rate of THB/USD and SET index to SET index. The dashed line indicates bootstrapped error bands for impulse response coefficients of Vector Auto-Regressive (VAR).

Figure 2. Impulse-response functions during the pre-Coup d'état 2006 to the Coup d'état 2006 


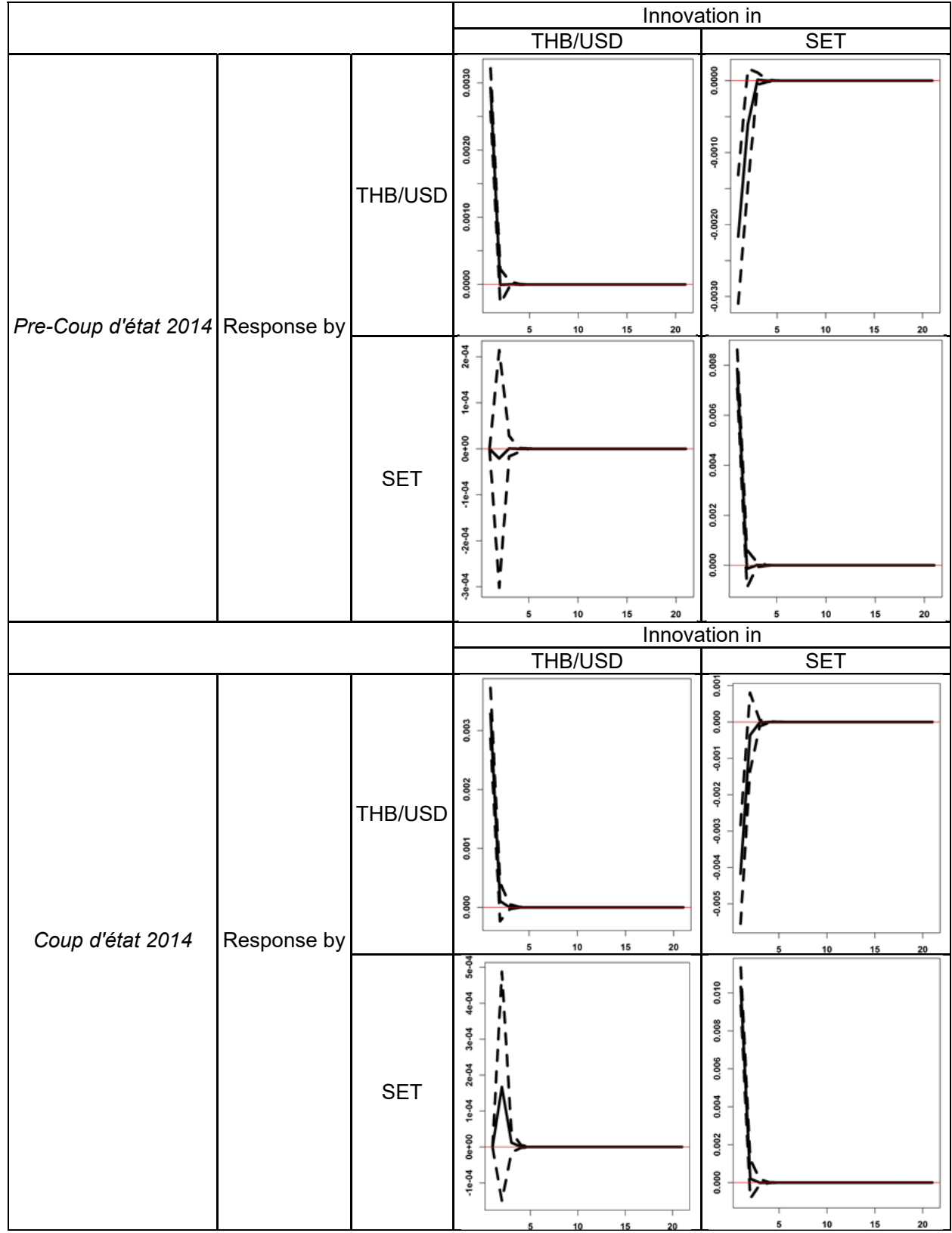

Notes: This figure shows impulse-response of the SET index and the exchange rate of THB/USD during the pre-Coup d'état 2014 and Coup d'état 2014. The subfigures identify the interaction of the SET index and the exchange rate of THB/USD by act as the response to the innovation and vice versa. As a result, the interactions provide as following; exchange rate of THB/USD to exchange rate of THB/USD, the exchange rate of THB/USD to SET index, SET index to exchange rate of THB/USD and SET index to SET index. The dashed line indicates bootstrapped error bands for impulse response coefficients of Vector Auto-Regressive (VAR).

Figure 3. Impulse-response functions during the pre-Coup d'état 2014 to the Coup d'état 2014 


\section{Discussions}

With the most frequent amount of Coup d'état in the Southeast Asia region, the analysis between these political issues and the financial market in Thailand becomes exceptionally interesting. However, after the Asian crisis on July 02, 1997, Thai Baht had been transformed from a pegged to a managed float regime. Thus, it allows us to analyze only two incidents of Coup d'état. Firstly, the Coup d'état 2006 began when the Royal Thai Army had succeeded to overthrow the democratic government from prime minister Thaksin Shinawatra on September 19, 2006. Until Thailand had a new prime minister from the election on January 29, 2008, then the period of being military rule had been not taken into account. Secondly, after the Royal Thai Army had seized power over elected prime minister Yingluck Shinawatra on May 22, 2014, Thailand had been imposed by martial law. Until January 26, 2016, the military junta had announced for the election.

To compare the effect of military and democratic government, we construct the pre-Coup d'état periods by counted as similar amount as Coup d'état periods. From the Johansen test results in table 3 , there are at most a long-run cointegrating relations between the SET index and the exchange rate of THB/USD during both periods of pre-Coup d'état. The results are supporting the evidence from Yagci (2018). When the military intervention attempts, there will be adversely affecting economic growth compared to the global trend. Although there were several massive street demonstrations against the government in Thailand during both periods of pre-Coup d'état, the financial market and the exchange rate acted as a steady condition. It may explain that the Coup d'états provoke the lower level of investor confidence and economic performance (Narayan \& Prasad, 2007; Jayaraman \& Choong, 2015).

As following the results of long-run cointegration during pre-Coup d'état periods, we further investigate the Granger causality test. The test provides that which parameter is better to predict another whether the SET index or the exchange rate of THB/USD. The results from table 4 demonstrate the uni-directional causality in pre-Coup d'état 2006, which the SET index can be predicting the exchange rate of THB/USD. On the other hand, pre-Coup d'état 2014 also provides the uni-directional causality, but the exchange rate of THB/USD can be predicting the SET index. Consequently, we cannot ascertain whether the SET index or the exchange rate of THB/USD is better to predict in long-run. We then extend the study into the short-run. In the short run, we implement the impulse-response functions to investigate the short-run interactions between the SET index and the exchange rate of THB/USD. The results from figure 2 and 3 show that the exchange rate of THB/USD is profoundly affecting the SET index while the SET index is weakly affecting the exchange rate of THB/USD.

To the contrary, the Coup d'état 2006 and Coup d'état 2014 have found no evidence on longrun relations. The causal relationships from table 4 show the uni-directional only Coup d'état 2014 but no indication on Coup d'état 2006. From figure 2 and 3, the short-run of the Coup d'état 2014 show that the SET index positively affects the exchange rate of THB/USD. However, the SET index negatively affects the exchange rate of THB/USD during the Coup d'état 2006. To the contrary, the Coup d'état 2006 and Coup d'état 2014 have found no evidence on long-run relations. The causal relationships from table 4 show the uni-directional only Coup d'état 2014 but no indication on Coup d'état 2006. From figure 2 and 3, the short-run of the Coup d'état 2014 show that the SET index positively affects the exchange rate of THB/USD. However, the SET index negatively affects the exchange rate of THB/USD during the Coup d'état 2006. The results are consistent with Alexis and Elias (2017), which mentioned that the government from the Coup d'état generates economic instability. Also, our findings reinforce the study of Jayaraman and Choong (2015) that the military coups provide financial market uncertainty.

\section{Implications and Conclusion}

In this study, we investigate and analyze between the exchange rate of Thai Baht and US dollar and the SET index during the recent of the Coup d'état in Thailand (2006-2016). The long-run analysis results show the cointegration during the pre-Coup d'état 2006 and the pre-Coup d'état 2014. But the Coup d'état 2006 and the Coup d'état 2014 show not cointegrated. Besides, Granger 
causality tests show the significant uni-directional causality in all periods, except during the Coup d'état 2006. The pre-Coup d'état 2014 and the Coup d'état 2014 show the exchange rate Grangercause the SET index. On the other hand, the pre-Coup d'état 2006 shows the SET index Grangercause the exchange rate of THB/USD. In short-run, the SET index shocks in all investigated periods show a negative effect on the exchange rate of THB/USD, except the Coup d'état 2014 shows a positive effect. In particular, our results are consistent with Dunning $(2005 \mathrm{c})$ that the change of political regime influences the financial market.

In summary, on the one hand, the evidence shows that the long-run relationship between the SET index and the exchange rate of THB/USD do not exist during the Coup d'état periods. On the other hand, the short-run results of the shocks from the exchange rate of THB/USD to the SET index show both negative and positive effects during the Coup d'état periods. Therefore, the period of political instability event adversely affects the relationship between the stock market and the exchange rate. We can conclude that, when the military has been taken place, the financial or economic strategies that compose of the stock market and the exchange rate will be mispricing in both long-run and short-run relationships.

\section{Reference}

Alesina, A., Özler, S., Roubini, N., \& Swagel, P. (1996). Political Instability and Economic Growth. Journal of Economic Growth, 1(2).

Alexis, D. \&, Elias, J., (2017). Political Economy of the Coup d'état in Brazil. Problemy Zarzadzania, 15(70)

Branson, W. H. (1981). Macroeconomic Determinants of Real Exchange Rates. https://doi.org/10.3386/w0801

Bunce, V. (1980). Changing Leaders and Changing Policies: The Impact of Elite Succession on Budgetary Priorities in Democratic Countries. American Journal of Political Science, 24(3).

Civilize, S., Wongchoti, U., \& Young, M. (2015). Military regimes and stock market performance. Emerging Markets Review, 22. https://doi.org/10.1016/j.ememar.2015.01.001

de Haan, J., \& Siermann, C. L. J. (1996). Political Instability, Freedom, and Economic Growth: Some Further Evidence. Economic Development and Cultural Change, 44(2).

Dickey, D. A., \& Fuller, W. A. (1981). Likelihood Ratio Statistics for Autoregressive Time Series with a Unit Root. Econometrica, 49(4). https://doi.org/10.2307/1912517

Dornbusch, R., \& Fischer, S. (1980). Exchange Rates and the Current Account. The American Economic Review, 70(5).

Dunning, T. (2005). Resource Dependence, Economic Performance, and Political Stability. Journal of Conflict Resolution, 49(4). https://doi.org/10.1177/0022002705277521

Fang, W. (2002). The effects of currency depreciation on stock returns: evidence from five East Asian economies. Applied Economics Letters, 9(3). https://doi.org/10.1080/13504850110054931

Frankel, J. A. (1984). Tests of Monetary and Portfolio Balance Models of Exchange Rate Determination. In Exchange Rate Theory and Practice. University of Chicago Press.

Gonzalo, J. (1994). Five alternative methods of estimating long-run equilibrium relationships. Journal of Econometrics, 60(1). https://doi.org/10.1016/0304-4076(94)90044-2

Granger, C W J. (1969). Investigating Causal Relations by Econometric Models and Cross-spectral Methods. Econometrica, 37(3). https://doi.org/10.2307/1912791

Granger, Clive W J, Huangb, B.-N., \& Yang, C.-W. (2000). A bivariate causality between stock prices and exchange rates: evidence from recent Asianflu. The Quarterly Review of Economics and Finance, 40(3). https://doi.org/10.1016/S1062-9769(00)00042-9

Ibrahim, M. H., \& Aziz, H. (2003). Macroeconomic variables and the Malaysian equity market: A view through rolling subsamples. Journal of Economic Studies, 30(1). https://doi.org/10.1108/01443580310455241

Jayaraman, T. \& Choong, Chee-Keong. (2015). Excess Liquidity in Fiji's Banking System: 2000-2011 An Empirical Study. Fijian Studies, 10(1)

Johansen, S. (1988). Statistical analysis of cointegration vectors. Journal of Economic Dynamics and Control, 12(2). https://doi.org/10.1016/0165-1889(88)90041-3

Johansen, S. (1991). Estimation and Hypothesis Testing of Cointegration Vectors in Gaussian Vector Autoregressive Models. Econometrica, 59(6). https://doi.org/10.2307/2938278

Kim, K.-H. (2003). Dollar exchange rate and stock price: evidence from multivariate cointegration and error correction model. Review of Financial Economics, 12(3). https://doi.org/10.1016/S1058-3300(03)00026-0

Lin, C.-H. (2012). The comovement between exchange rates and stock prices in the Asian emerging markets. International Review of Economics \& Finance, 22(1). https://doi.org/10.1016/j.iref.2011.09.006 
Lumiajiak, S., Treepongkaruna, S., Wee, M., \& Brooks, R. (2014). Thai Financial Markets and Political Change. Journal of Financial Management, Markets and Institutions, (1). https://doi.org/10.12831/77234

Mancur, O. (1991). Autocracy, Democracy and Prosperity (R. Zeckhauser, Ed.). MIT Press.

Maysami, R. C., \& Koh, T. S. (2000). A vector error correction model of the Singapore stock market. International Review of Economics \& Finance, 9(1). https://doi.org/10.1016/S1059-0560(99)00042-8

McGuire, M. C., \& Olson, M. (1996). The Economics of Autocracy and Majority Rule: The Invisible Hand and the Use of Force. Journal of Economic Literature, 34(1).

Monty, G. M., \& Donna, R. M. (2018). Coup d'etat Events, 1946-2017. Center for Systemic Peace. http://www.systemicpeace.org/inscrdata.html

Narayan, P. K. \& Prasad, B.C. (2007), The long-run impact of coups on Fiji's economy: evidence from a computable general equilibrium model. Journal of International Development, 19. https://doi.org/10.1002/jid.1296

Pan, M.-S., Fok, R. C.-W., \& Liu, Y. A. (2007). Dynamic linkages between exchange rates and stock prices: Evidence from East Asian markets. International Review of Economics \& Finance, 16(4). https://doi.org/10.1016/j.iref.2005.09.003

Prasirtsuk, K. (2007). From Political Reform and Economic Crisis to Coup d'état in Thailand: The Twists and Turns of the Political Economy, 1997-2006. Asian Survey, 47(6). https://doi.org/10.1525/as.2007.47.6.872

Sui, L., \& Sun, L. (2016). Spillover effects between exchange rates and stock prices: Evidence from BRICS around the recent global financial crisis. Research in International Business and Finance, 36. https://doi.org/10.1016/j.ribaf.2015.10.011

Tsagkanos, A., \& Siriopoulos, C. (2013). A long-run relationship between stock price index and exchange rate: A structural nonparametric cointegrating regression approach. Journal of International Financial Markets, Institutions and Money, 25. https://doi.org/10.1016/j.intfin.2013.01.008

Wongbangpo, P., \& Sharma, S. C. (2002). Stock market and macroeconomic fundamental dynamic interactions: ASEAN-5 countries. Journal of Asian Economics, 13(1). https://doi.org/10.1016/S1049-0078(01)00111-7

$\mathrm{Wu}, \mathrm{Y}$. (2000). Stock prices and exchange rates in VEC model - The case of Singapore in the 1990s. Journal of Economics and Finance, 24(3). https://doi.org/10.1007/BF02752607

Yagci, A. H. (2018). The political economy of coups d'état: a general survey and a local theory for Turkey. Turkish Studies, 19(1). https://doi.org/10.1080/14683849.2017.1396894 